\title{
Lithospheric Geotraverses in Central and Eastern Europe
}

\author{
by Anatoly V. Chekunov and Vsevolod B. Sollogub
}

As the Global Geoscience Transects (GGT) project of the International Lithosphere Program gathers momentum, it is interesting to note the existence in Eastern Europe of a 25 year-old program involving geological and geophysical profiling of the crust and upper mantle. Participants in this activity, reviewed here, have enthusiastically endorsed GGT and will contribute actively to it. (Ed.)

\section{Background to the Project}

At the VI Congress of the Carpatho-Balkan Geological Association (CBGA) held in Poland in September 1963, Soviet geoscientists, with support from Yugoslavian colleagues, proposed a new program for studying the deep structure of Central and Eastern Europe down to the Iohorovicic (M) discontinuity. The program was adopted by CBGA and the Commission for Multilateral Cooperation of the Academies of Sciences of Socialist Countries on the complex problem "Planetary Geophysics Studies" (CAPG). Thus, the Lithospheric Geotraverses Project (LGP) for Central and East Europe was born (Subbotin et al., 1965; Chekunov et al., 1963-1964).

The central idea behind LGP, which has been coordinated by the Institute of Geophysics of the Ukraine Academy of Science (see Table 1), was that an understanding of the distribution and main features of structural units and the associated mineral resources requires both study of deeper parts of the crust and upper mantle and a linking of data on the upper and lower lithosphere. The project was to be implemented using combined geological and geophysical techniques, primarily deep seismic sounding (DSS), integrated with gravimetric, magnetic and electrical studies. The data thus obtained would be conrdinated with results from drilling, geological mapping and other geological research.

The DSS investigations began in the summer of 1964 along eight geotraverses crossing major geological features of Central and Eastern Europe (Fig. 1). In addition, an impressive number of national DSS lines was run in particiDating countries (Fig. 2). The main task of this first stage was to construct DSS models using a uniform technique based on continuous profiling, in order to obtain a consistent structural basis for the geotraverses. This work was completed by the beginning of the 1970s, and many results were published at the time (Anon, 1972a, 1972b; Sollogub et al., 1971).

Major Results from Deep Seismic Studies

The DSS models have made possible a great increase in the depth range studied by gravimetry, since they provide information for calculating the variation of density at depth. Estimates of the thickness of the total crust, its "granitic" and "basaltic" lavers, and the low velocity layer positions derived from DSS place constraints on ealculations of heat generation in the crust and mantle, on the distribution of temperature at depth and on the location of presumed zones of rock melting. Similarly, seismic, density and geothermal (Curie isotherm position) constraints reduce the range of options in magnetometry and increase its depth and accuracy.

The 1970 s were marked by a tendency to combine geophysical techniques, and there was a general feeling that although a single method could provide sufficiently accurate information for considerable depths, it could only give a one-sided characterization of the target. A close approximation to reality conld only be achieved through integration of different geophysical techniques and utilization of the entire data set.

TABLE 1: Institutes Involved in CAPG

$\begin{array}{ll}\text { Bulgaria: } & \begin{array}{l}\text { Geophysical Institute, Bulgarian } \\ \text { Academy of Sciences (Sofia) }\end{array} \\ \text { Czechoslovakia: } & \begin{array}{l}\text { Institute of Applied Geophysics (Brno) } \\ \text { Geophysical Institute of the Czech } \\ \text { Academy of Sciences (Prague) }\end{array} \\ \text { Germany }(D D R) \quad & \begin{array}{l}\text { Central Institute of Physies of the } \\ \text { Earth, DDR Academy of Sciences } \\ \text { (Potsdam) } \\ \text { Karl-Marx University (Leipzig) } \\ \text { Geophysical Institute of the Mining } \\ \text { Academy (Freiberg) }\end{array}\end{array}$

Hungary: . Geodetic and Geophysical Research Institute of the Hungarian Academy of Sciences (Sopron)

Institute of Geophysies, University Lorand Eötrös (Budapest)

Poland: . Institute of Geophysies of the Polish Academy of Sciences (Warsaw)

- Institute of Geology of the University of Warsaw

Romania: $\quad$ Institute of Applied Geophysics (Bucharest)

- Center for Earth Physies and Seismology (Bucharest-Magurele)

Yugoslavia: - University of Beograd (Belgrade)

U.S.S.R.: - Institute of Physies of the Earth, U.S.S.R. Academy of Sciences (Moscow)

Leningrad Mining Institute

- Institute of Geology of Kola Branch of U.S.S.R. Academy of Sciences (Apatity, Murmansk region) Association "Ukrgeophysica" (Kiev) All-Union Research Institute of Geophysies (Moscow) 


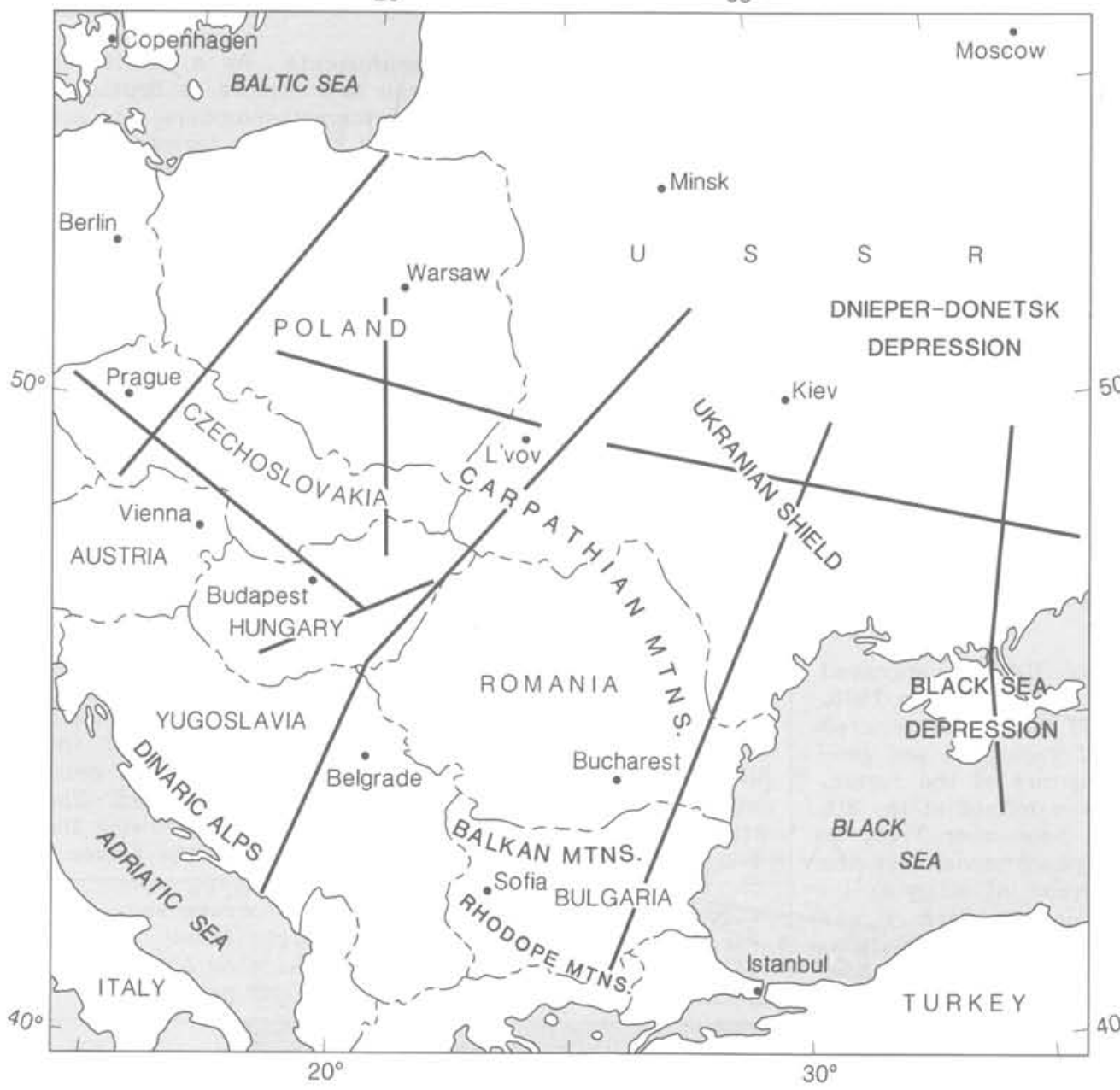

sharp continuous interface. These zones are layered and show on the seismic crosssection as numerous short reflectors. Crustal material is evidently intermingled here with mantle, the importance of the latter component growing with depth. We suggest that separate lenses, lamellae and other isolated or nearly isolated bodies of mantle material occurring in the crust are succeeded at depth by packages, massifs and thick layers of such bodies, and that these in turn pass downwards into pure mantle with occasional small inclusions of crustal rocks.

Thin layering is characteristic not only of the Moho (M) discontinuity, but also of the entire consolidated crust, though here it is less pronounced and mainly dispersed. The seismic boundaries marking this layering are generally $\mathrm{ra}^{-}$ ther local in extent, but sometimes they concentrate in extended zones to form continuous, quasi-sham, regional, intracrustal horizons that divide the crust into large structural complexes or slabs.

$40^{\circ}$ The geological units of Central and Eastern Europe have now been classified according to their deep crustal structure

Figure 1: Lines for deep seismic sounding proposed in 1964.

However, even the most comprehensive geophysical model cannot yield a complete understanding of the lithosphere without the geological component. In the LGP this had been realized from the very beginning (Chekunov and Sollogub, 1985), and geological considerations were the basic ones in selecting the study areas, the optimal positions of geophysical lines, techniques to be used, observation systems and so forth. The initial geological models were tested and progressively corrected in further work, until a consistency of data was achiever.

In this way, it was established that the erust and uppermost mantle have a complex layered or block structure, with gradual variations and inversions of physical parameters and a varying number of interfaces between different blocks. This is illustrated by Figure 3, a sample profile extending westwards from the Crimea into Romania. Here the blocks are bounded by major deep faults that vary in extent, orientation and dip; these include the horizontal faults that are responsible for the structural subdivision of the lithosphere. Tectonism in the asthenospheric part of the mantle is obvious, for it induces strains and displacements in the lithosphere. The largest transerustal faults originate in the mantle and penetrate upwards into the crust, where they branch out to form "swarms" of minor disruptions. The faults affect substantially the distribution and concentration of ore minerals at the surface or in near-surface layers, and this factor should, of course, be taken into account in prospecting for new deposits.

It has been established that the crust-to-mantle boundary is complex and diverse and in many places is represented by transitional zones of varying thickness, rather than by a and the nature of their crust-mantle transition. This has led to a deeper insight into the evolution of the crust-mantle transition and of the lithosphere on the whole. On this basis, criteria have been derived for detecting the M discontinuity beneath constructive and destructive regions with a crust-mantle "mix."

Comparison with surface geology produced the idea of a stratified M discontinuity. This was displayed in schemes in which the age of the base of the erust varied. The possibility of determining the spatial orientation of structures of different ages within the lithosphere provides the investigator with a key to the deep stage-by-stage tectonic zoning and reconstruction of geodynamic situations of the past.

Comparison between geophysical and metallogenetic models has shown that the concentration of ore minerals forming endogenic and metamorphogenic occurrences at the Earth's surface depends on the thickness and composition of the erust. The recognition of the endogenic origin of metals formed at a great depth and subsequently emplaced in the uppermost part of the crust encourages further comprehensive geological, metallogenic and geophysical studies of the relations between ore genesis and the structure, composition and physical state of the tectonosphere.

\section{The Current Phase}

Analysis of the DSS results (Sollogub et al., 1978; Sollogub, 1980 ) enabled us to formulate, by the end of the $1970 \mathrm{~s}$, a long-term program of comprehensive studies of the lithosphere (Chekunov and Sollogub, 1985) integrating geophysical, geological and geochemical data. This program includes the following items, each based on the previous LGP studies. 
Geophysical cross-sections of the crust and uppermost mantle are being compiled to integrate the entire set of the physical parameters studied. These sections will then be transformed into petrological profiles using data on physical properties of rocks and minerals at high pressures and temperatures characteristic of great depths. On this basis various "geostructure series" (a succession of regional structures) will be constructed, which correspond to different periods of geological evolution and which permit detection of successive changes in structure and composition of the lithosphere and tectonosphere. When combined with other geological data, these reconstructions will shed light on the physical and chemical nature of processes operating at great depths.

These studies should provide new information on the characteristic features of mineral resources formed at depth and should aid in exploring for new ore deposits. In essence, the LGP is now evolving from earlier dominantly qualitative studies to rigorous methods of analysis, which will enable a more extensive synthesis and interpretation of geological and geophysical data.

In 1985, the 18th CAPG meeting (Sochi, U.S.S.R.) approved a continuation of the project for the period 1986 to 1990 . The goal is to develop the theory and techniques required for a comprehensive interpretation of geological and geophysical data on the lithospheric structure of the region. The main task for the coming years was defined at the 8 th CBGA Congress (Krakov, Poland) in September 1985, as construction of comprehensive geophysical models for the regional tectonosphere with the purpose of studying its structure, physical state, composition and evolution. It was noted that many critical problems of tectonics, magmatism, ore formation and metallogeny cannot be solved without geophysical data on deep crustal and upper mantle structure, while geological interpretation of geophysical data is impossible unless data on tectonics, magmatism, etc. are involved.

Although many aspects of the interpretation of geophysical data have yet to be solved, some new advances have been made. For example, combining explosion seismology with gravimetry is proving to be a valuable technique, involving computerized fitting of seismic models to the gravity field. A method for constructing geothermal models and temperature distributions for the lithosphere has also been developed. The algorithms and computer programs obtained by using the correlational method enable the construction of a magnetic model for the lithosphere compatible with the gravity field and DSS data (Starostenko et al., 1988). Models and methods for quantitative calculations of the electromagnetic models consistent with temperature distribution have also been devised.

Improvements have also come from the use of extended seismic lines, from higher resolution of reflection records and utilization of magnetotelluric sounding and heat flow measurements. As a result the East-European geotraverses can now explore to depths of 200 to $250 \mathrm{~km}$, that is, down to the asthenosphere. We are thus at the beginning of a study of the entire tectonosphere. Moreover, it may soon be possible to compile systematic three-dimensional geological and geophysical models.

The data collected on the LGP geotraverses have been described by Sollogub and Chekunov (1983a, b), Chekunov and Sollogub (1985), Sollogub (1986), Yanshin and Beus (1986) and Chekunov (1987). The study will be concluded by 1990 with the publication of eight volumes under the title "The Lithosphere of the Central and East Europe."

\section{A Tectonospheric Model}

As a result of this work a tectonospheric model has been compiled. This displays a heterogeneous structure and consists of five complexes of different composition and type of deformation. The structural relations between the stages, as well as strain-depth variations have been examined. The heterogeneities are classified as static (relict) or dynamic (mobile), concentrated or distributed.

The history of the tectonosphere has been reconstructed and the features of its evolution exhibited. Against the background of a general decrease in temperature and tectonic activity of the mantle, a successive accretion of the lithospheric and crustal thicknesses took place, the crust being granitized, cooled, strengthened and stabilized. The process has repeated itself, attenuating and narrowing the area affected. By releasing heat and fluids, the astheno-

Figure 2: DSS lines and integrated geotraverses carried out by 1987. Thinner straight lines

indicate DSS traverses, thicker ones show LGP geotraverses incorporated into the GGT program.

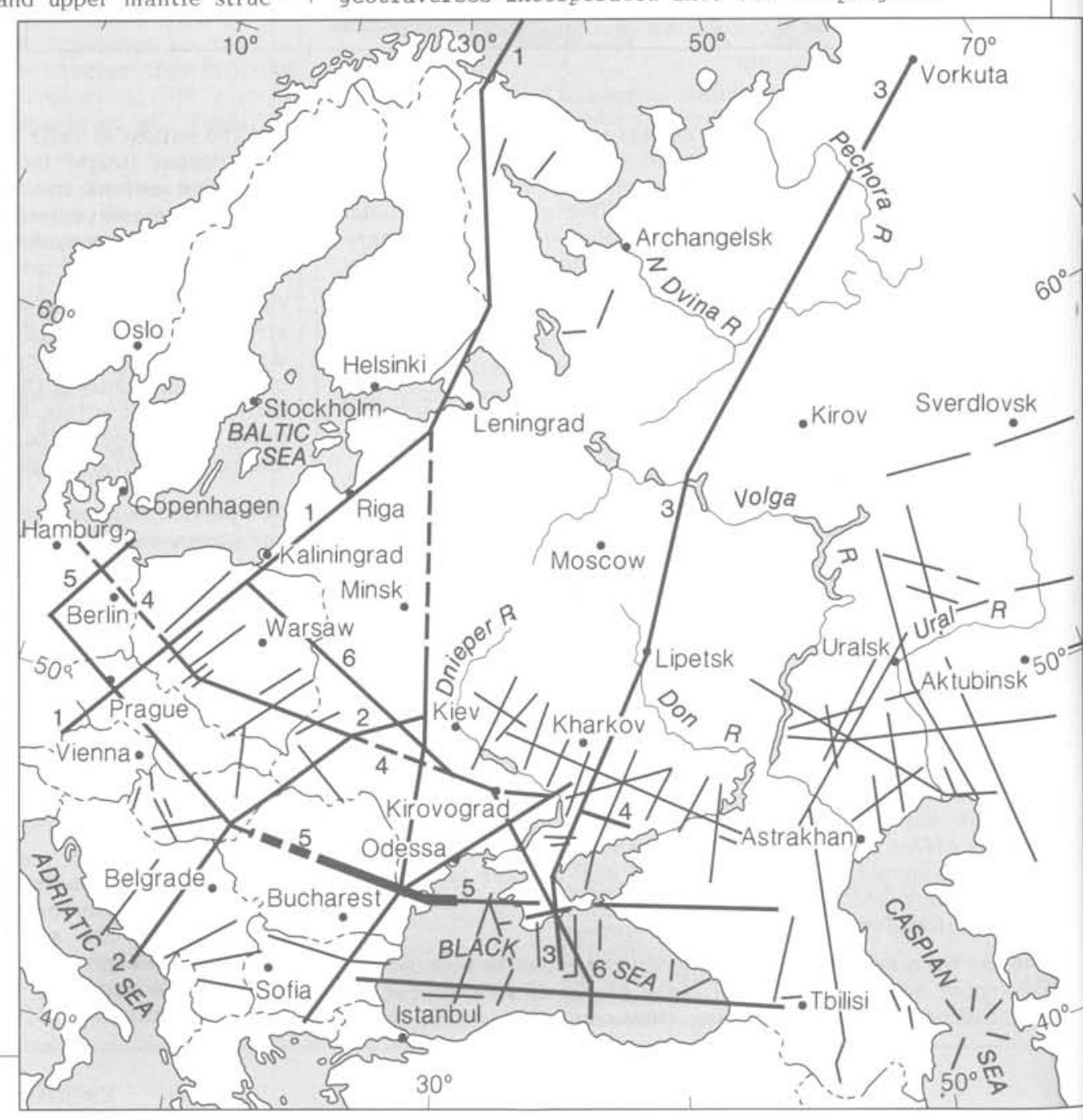




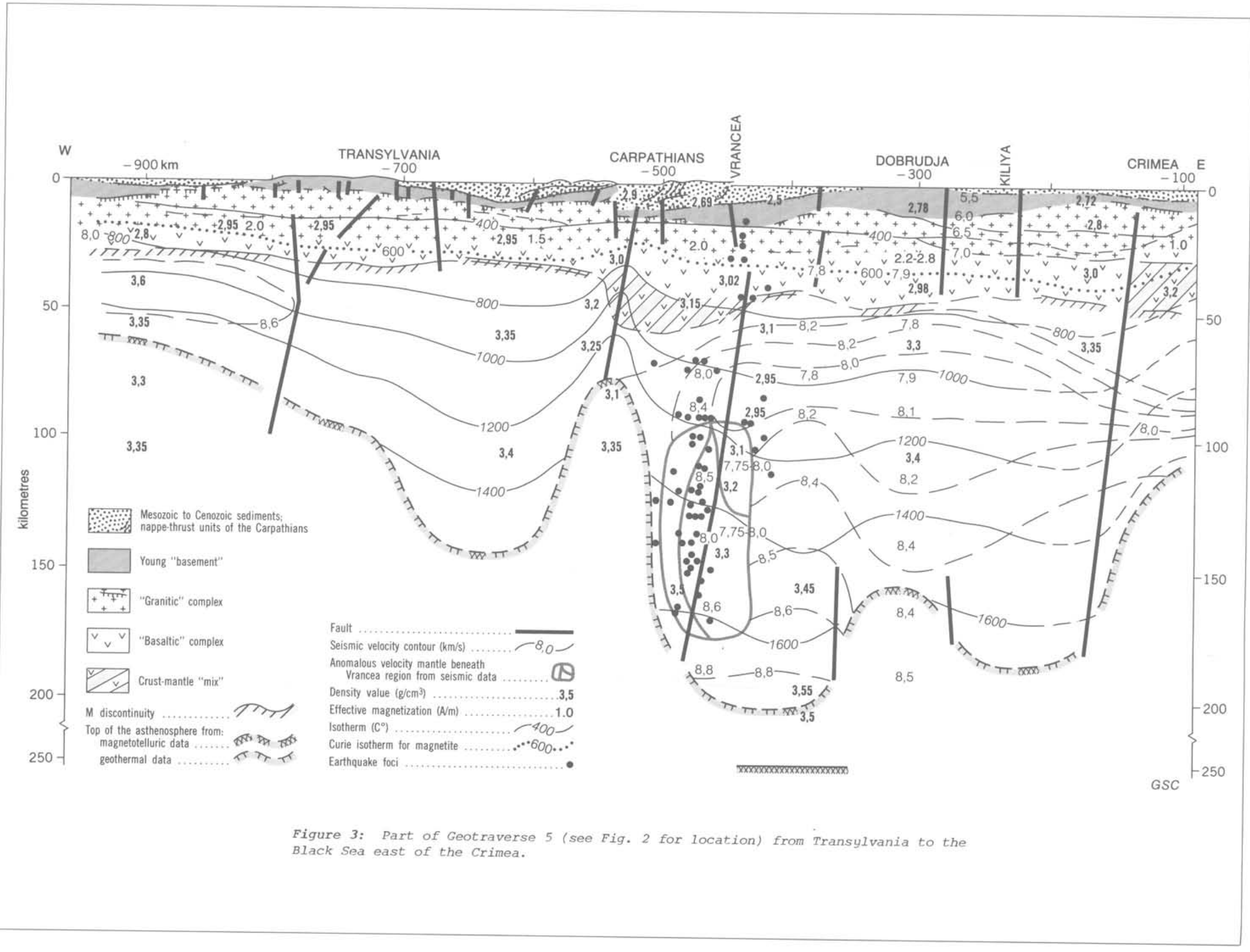


sphere became "energetically" exhausted, followed by a re-accumulation of energy and regeneration of activity. This style of destruction and of rifting related to the latter changed throughout time, reflecting a general evolution in the structure, physical properties and energy state of the tectonosphere. The tectonic pulse spread upwards from the asthenosphere to bring about the deformation and seismicity of the lithosphere. Dissipation of this pulse led to a lateral re-distribution of matter within the lithospheric complexes, especially those closer to the asthenosphere.

Carriers of this activity are represented mainly by asthenoliths of varying scale and depth of origin. Moving from one lithospheric level to another, these cooled and changed their configuration to form apophyses. They pulled the lithosphere apart to form extension structures, which were then filled by basic magma. The compression on the periphery had various results including crustal thickening and the formation of nappes and thrusts, accretion lenses, and relict seismicity. Associated with the asthenoliths were an abnormally raised mantle, a thin crust, a thick cover of loose sediments, young basic voleanism, extension and destruction, recent movements and seismicity. On the whole, this model shows that the tectonosphere evolves as a discrete, hierarchic, physically open system tending to self-organization and to a minimum of energy.
Academician A. Chekunov is Director of the Institute of Geophysics, Academy of Sciences of the Ukrainian S.S.R. (Prospect Palladina, 32, Kiev 252680, U.S.S.R.). He heads the CAPG project described in this review and is Chairman of the Scientific Council on the Tectonosphere of the Ukraine and Editor-in-Chief of the Geophysical Journal published in Kiev.

The late Prof. V. Sollogub was a Corresponding Member of the Ukrainian Academy of Sciences and Professor at the Institute of Geophysies (Kiev). A former head of the CAPG project, he was Chairman of the Geophysical Committee of the Ukrainian Academy of Sciences and a specialist in seismic methods and the integration of geological and geophysical data.
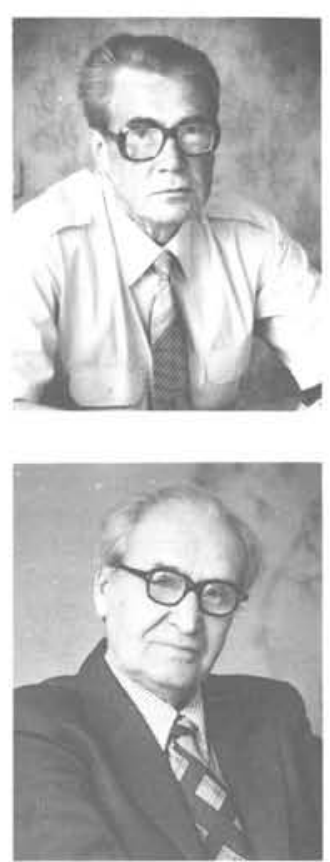

\section{References}

Anon, 1972a. The erustal structure of Central and Southeastern Europe based on the results of explosion seismology. Müszaki Könyvkiado, Budapest, 172p.

Anon, 1972b. Die Struktur der Erdkruste Mittel und Süidosteuropas nach Angaben der Tiefenseismik. Geodätische und Geophysikalische Veröffentlichungen, Series III, no. 27, Berlin, 185p.

Chekunov, A.V., 1987. The principles of the structure and evolution of the tectonosphere in the south of the European part of the U.S.S.R. (In Russian). Geotektonika, no. 5, p. 25-41.

Chekunov, A.V., Ciric, B.M., Prosen, D.I., et al., 1963-1964. Investigation of the constitution of deep zones of the earth's crust in the Carpatho-Balkanic and surrounding areas. Bulletin of the Institute of Geological and Geophysical Research, Series c, no. 4-5, Beograd, p. 5-12.

Chekunov, A.V. and Sollogub, V.B., 1985. Strategy of geophysical studies of the lithosphere in the Ukraine. (In Russian). Geofizicheskii Zhurnal, v. 7, no. 6, p. 22-42.

Global transects, 1986. A new ICL program. Episodes, v. 9, no. 1 , p. 27.

International Lithosphere Program, 1985. Report no. 6, Newsletter, Secretariat of the Inter-Union Commission on the Lithosphere. Utrech, Netherlands, p. 1-2.

Sollogub, V.B. (ed.), 1980. Crustal structure of Central and East Europe from geophysical data. (In Russian). Naukova dumka, Kiev, 206p.

Sollogub, V.B., 1986. The lithosphere of the Ukraine. (In Russian). Naukova dumka, Kiev, 184p.

Sollogub, V.B. and Chekunov, A.V., 1983a. The lithosphere of Southeast Europe using geophysical data. (In Russian). Izvestiya AN S.S.S.R., seriya geologicheskaiya, no. 12, p. 3-12.

Sollogub, V.B. and Chekunov, A.V., 1983b. The lithosphere of the Ukraine. First Break, v. 1, no. 6, p. 9-17.

Sollogub, V.B. et al. (eds.), 1971. Crustal structure in Central and South-eastern Europe (from the explosion seismology data). (In Russian). Naukova dumka, Kiev, 286p.
Sollogub, V.B. et al. (eds.), 1978. Structure of the earth's crust and upper mantle in Central and East Europe. (In Russian). Naukova dumka, Kiev, 27lp.

Starostenko, V.I., Kostyukevich, H.S. and Koslenko, V.G., 1988. Combined interpretation of seismicity and gravity observations. I-principles and methods. (In Russian). Isvestiya Academia Nauk S.S.S.R., no. 4, p. 33-49.

Subbotin, S.I., Sollogub, V.B., Slavin, V.I. and Chekunov, A.V., 1965. On the studies of deep crustal structure in the Carpatho-Balkan region. (In Russian). Proceedings of VI Carpatho-Balkan Geological Association Congress. Naukova dumka, Kiev, p. 86-97.

Yanshin, A.L. and Beus, A.A. (eds.), 1986. Dynamics and evolution of the lithosphere. (In Russian). Nauka, Moscow, 231p. 